\title{
Analysis of a Small Sample of Caddo Ceramic Sherds from the T. M. Sanders Site (41LR2), Lamar County, Texas
}

Timothy K. Perttula

Heritage Research Center, Stephen F. Austin State University

Follow this and additional works at: https://scholarworks.sfasu.edu/ita

Part of the American Material Culture Commons, Archaeological Anthropology Commons, Environmental Studies Commons, Other American Studies Commons, Other Arts and Humanities Commons, Other History of Art, Architecture, and Archaeology Commons, and the United States History Commons

Tell us how this article helped you.

This Article is brought to you for free and open access by the Center for Regional Heritage Research at SFA ScholarWorks. It has been accepted for inclusion in Index of Texas Archaeology: Open Access Gray Literature from the Lone Star State by an authorized editor of SFA ScholarWorks. For more information, please contact cdsscholarworks@sfasu.edu. 
Analysis of a Small Sample of Caddo Ceramic Sherds from the T. M. Sanders Site (41LR2), Lamar County, Texas

\section{Creative Commons License}

\section{(c) (i) (8)}

This work is licensed under a Creative Commons Attribution-NonCommercial 4.0 International License 


\title{
Analysis of a Small Sample of Caddo Ceramic Sherds from the T. M. Sanders Site (41LR2), Lamar County, Texas
}

\author{
Timothy K. Perttula
}

\section{INTRODUCTION}

This article documents several small collections of Caddo ceramic vessel sherds from the T. M. Sanders site (4ILR2) in northwestern Lamar County, in East Texas. These vessel sherds were collected from the surface in 2011 and 2012, and provided to the author for analysis.

\section{Site Setting}

The T. M. Sanders site (41LR2) is one of the more important (although still not well known or intensively studicd) Caddo sites known in East Texas, primarily because of its two earthen mounds and well-preserved mortuary features of Caddo elite persons buried in Mound No. 1. Archaeological work began at the site in 1931 by The University of Texas at Austin (Jackson et al. 2000), with sporadic work by the Dallas Archeological Society in the 1940s (Hanna 1950: Wilson 1948; Wilson and Housewright 1941). Archaeological and bioarchaeological interpretations of the findings from this work at the Sanders site began with Krieger's analyses $(1946,2000,2009)$ of the burial features and associated funerary objects (including marine shell gorgets, shell beads, arrow points, and ceramic vessels). These analyses continue to the present day, and rely upon the reanalysis and reinterpretation of the archaeological (Bruseth et al. 1995; Hamilton 1997; Perttula 1997; Schambach 1995, 1999, 2000a, 2000b) and bioarchaeological (Maples 1962; Wilson 1993, 1994, 1995, 1997; Wilson and Cargill 1993; Wilson and Derrick 1996) materials recovered in the Jackson et al. (2000) work.

Although the Sanders site is not dated by radiocarbon analyses, the general consensus is that the main Caddo occupation took place around ca. A.D. 1100-1300 (see Bruseth 1998), contemporaneous with related sites downstream along the Red River near its confluence with the Kiamichi River, and other sitcs in the Sabine River basin (see Krieger 1946, 2009). A late 17th-early 18th century Caddo occupation is also present at the Sanders site, but remains poorly known (e.g., Bell et al. 1967:Figure 1; Harris et al. 1965:288).

\section{Sherd Samples}

The ceramic vessel sherds $(n=53)$ are from three different areas at the Sanders site: (1) an area just north of Mound 1 at the Sanders site (see Jackson et al. 2000:10), with two sherds: (2) 20 sherds from Mound 2; and (3) 31 sherds from the fields south of the two mounds. Grog-tempered ceramics, from both plain and decorated vessels, are commonplace in the ca. A.D. 1100-1300 ceramic assemblage from the Sanders site (see Krieger 2000). More than $84 \%$ of the sherds in these collections are grog-tempered, including $86 \%$ of the plain rim, body, and base sherds, and $80 \%$ of the decorated rim and body sherds. There are two (3.8\% of the sherd sample) plain bone-tempered sherds and two (3.8\%) grog-bone-tempered sherds (both decorated), and these sherds are likely part of the ca. A.D. 1100-1300 assemblage. These sherds were generally fired in a reducing or low oxygen fire, and cooled in the open air, leaving one or both vessel surfaces with a brown or yellowish-brown color (see Teltser 1993:Figure 2f-h).

There are three plain rims (two grog- and one bone-tempered) in the collections, all with direct rim profiles and flat lips. These are from large bowls or jars, with rim wall thicknesses ranging from $8.6 \pm 0.4$ 
$\mathrm{mm}$ (grog-tempered rims) to $8.8 \mathrm{~mm}$ (bone-tempered rim). The plain grog-tempered body sherds are $7.41 \pm$ $1.19 \mathrm{~mm}$ thick, and base sherds for both the grog-tempered $(11.6 \pm 1.0 \mathrm{~mm})$ and bone-tempered $(11.6 \mathrm{~mm})$ wares are thick and flat disks.

The 10 decorated sherds are from Mound $2(n=4)$ and the fields south of the mounds $(n=6)$. The one decorated grog-tempered rim sherd ( $5.4 \mathrm{~mm}$ thick) has an horizontal engraved line encircling the rim, above an area of cross-hatched engraved lines (Figure 1c). Vessels with this design-with the areas of cross-hatching filling engraved triangles pendant from a horizontal engraved line-have been documented from several burial features in Mound 1 (Jackson et al. 2000:61d, 63c, 83). Two other engraved body sherds (6.5-6.9 mm thick) have single straight or multiple parallel lines, including one bottle sherd (Figure lb).

Four body sherds have incised decorations: widely-spaced parallel incised lines $(n=1)$ or single straight incised lines $(n=3)$. These sherds are from jars with thick body walls (ranging from 7.9-10.3 mm). One grog-tempered body sherd ( $8.9 \mathrm{~mm}$ thick) from Mound 2 has linear fingernail impressed rows (see Figure 1a); this is likely from a Monkstown Fingernail Impressed jar. The last two decorated body sherds - both grog-tempered and with thin vessel walls $(5.0-7.0 \mathrm{~mm})$ - have short sections of narrow and straight appliqued ridges (see Figure 1d-e). Krieger (2000:141) noted that some grog-and bone-tempered vessels at the Sanders site had sets of appliqued fillet ridges along the shoulders, and the two sherds in the collections may be from such thin-walled jars.

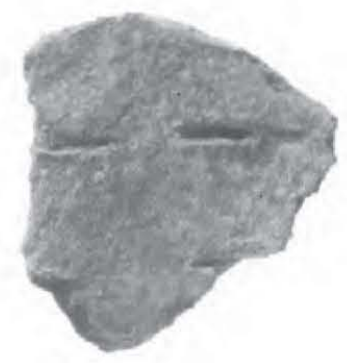

a
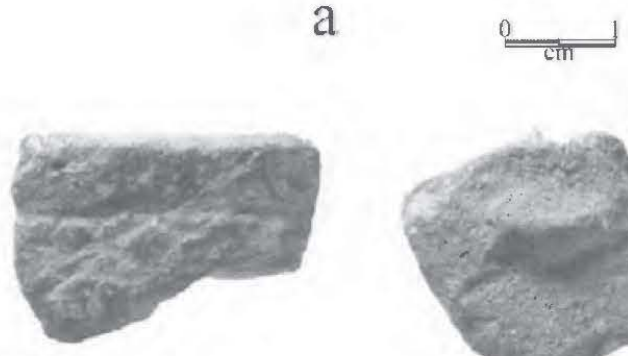

$\mathrm{C}$

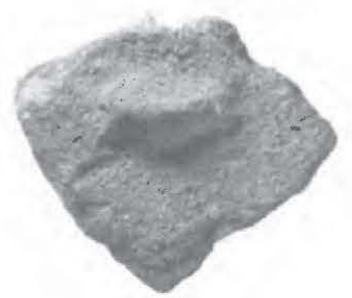

d

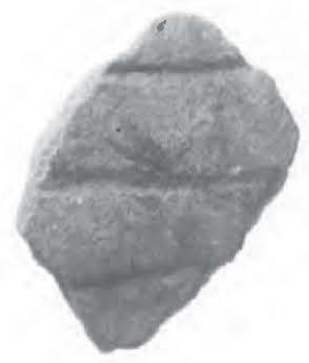

b

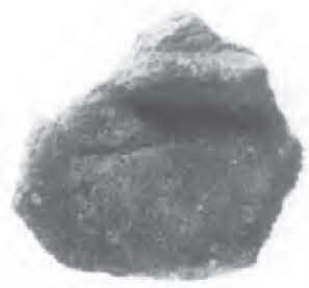

e

Figure 1. Decorated sherds in the sherd samples from the T. M. Sanders site: a, linear fingernail impressed rows; b, parallel engraved lines (bottle sherd); c, horizontal and cross-hatched engraved rim; d-e, straight appliqued ridges.

A later, post-A.D. 1300, occupation is represented in the collections by four plain shell-tempered body and base sherds; these were found on Mound 2 and in the fields south of the mounds. Krieger (2000) documented shell-tempered sherds and vessel sections in previous analyses of the Sanders ceramic assemblage. The plain shell-tempered body sherds in this collection are from relatively thin-walled vessels $(6.27 \pm 0.09$ $\mathrm{mm})$ with thick $(10.6 \mathrm{~mm})$ and flat bases. 


\section{SUMMARY AND CONCLUSIONS}

The small sample of ceramic vessel sherds documented from several locations at the T. M. Sanders site is dominated by grog-, grog-bone, and bone-tempered plain and decorated wares, including bowls, jars, and bottles. These sherds are associated with the ca. A.D. 1100-1300 Caddo occupation at the site, and are from mound and non-mound domestic contexts. The decorated sherds at the site include engraved fine wares (30\% of the decorated sherds) and utility wares with fingernail impressed, incised, and appliqued decorations ( $70 \%$ of the decorated sherds). Less than $8 \%$ of the sherds in the collections are from shell-tempered vessels. This ware, which includes only plain body and base sherds, are from a later post-A.D. 1300 Caddo occupation, as Caddo potters on the Red River did not manufacture shell-tempered ceramic vessels in any quantity until after this time (Perttula et al. 2012).

\section{ACKNOWLEDGEMENTS}

1 want to thank Julia Trigg Crawford and P. Shawn Marceaux for the opportunity to analyze several small surface collections of Caddo ceramic sherds from the Sanders site. Lance Trask took the photographs of selected decorated sherds in the collections.

\section{REFERENCES CITED}

Bell, R. E., E. B. Jelks, and W. W. Newcomb (assemblers)

1967 A Pilot Study of Wichita Indian Archeology and Ethnohistory. Final Report for Grant GS-964, National Science Foundation, Washington, D.C.

Bruseth, J. E.

1998 The Development of Caddoan Polities along the Middle Red River Valley of Eastern Texas and Oklahoma. In The Native History of the Caddo: Their Place in Southeastern Archeology and Ethnohistory, edited by T. K. Perttula and J. E. Bruseth, pp. 47-68. Studies in Archeology 30. Texas Archeological Research Laboratory, The University of Texas at Austin.

Bruseth, J. E., D. E. Wilson, and T. K. Perttula

1995 The Sanders Site: A Spiroan Entrepot in Texas? Plains Anthropologist 40(153):223-236.

Hamilton, D. L.

1997 Observations on Caddoan Burial Practices at the Sanders Site (4lLR2). Bulletin of the Texas Archeological Society 68:115-134.

Hanna, H., Jr.

1950 Three Burials from Mound 2, T. M. Sanders Site. The Record 8(4):16-19. Dallas Archeological Society, Dallas.

Harris, R. K., 1. M. Harris, J. C. Blainc, and J. Blaine

1965 A Preliminary Archeological and Documentary Study of the Womack Site, Lamar County, Texas. Bulletin of the Texas Archeological Society 36:287-363.

Jackson, A. T, M. S. Goldstein, and A. D. Krieger

2000 The 1931 Excavations at the Sanders Site, Lamar County, Texas: Notes on the Fieldwork, Human Osteology, and Ceramics. Archival Series 2. Texas Archeological Research Laboratory, The University of Texas at Austin. 
Krieger, A. D.

1946 Culture Complexes and Chronology in Northern Texas, with Extensions of Puebloan Datings to the' Mississippi Valley. Publication No. 4640. The University of Texas, Austin.

2000 The Pottery of the Sanders Farm. In The 1931 Excavations at the Sanders Site, Lamar County, Texas: Notes on the Fieldwork, Human Ostenlogy, and Ceramics, by A. T. Jackson, M. S. Goldstein, and A. D. Krieger, pp. 131-144. Archival Series 2. Texas Archeological Research Laboratory, The University of Texas at Austin.

2009 Archaeological Horizons in the So-Called Caddo Area. Archival Series 3. Texas Archeological Research Laboratory, The University of Texas at Austin.

Maples, W. R.

1962 A Morphological Comparison of Skeletal Material from Sanders Focus and from Fulton Aspect. Master's thesis, Department of Anthropology, The University of Texas at Austin.

Perttula, T. K.

1997 Sabine River and Middlc Red River Ceramics: Musings on the Ceramic Data used in Schambactl's "Continuing the Discussion of the Spiroans and Their Entrepots." Caddoan Archeology 8(3):9-18.

Perttula. T. K., M. B. Trubitt, and J. S. Girard

2012 The Use of Shell-Tempered Pottery in the Caddo Area of the Southeastern United States. Southeastern Archaeology 30(2):242-267.

Schambach, F. F.

1995 A Probable Spiroan Entrepot in the Red River Valley in Northeast Texas. Caddoan Archeology Newsletter 6(1):9-25.

1999 Deconstructing the "Sanders Focus" and "Sanders Phase": A Reply to Perttula Regarding the Tuxonomy and Significance of the So-Called Sanders Focus, or Sanders Phase Pottery of Northeast Texas and Southeast Oklahoma. Caddoan Archeology 9(3-4):3-55.

2000a The Significance of the Sanders Site in the Culture History of the Mississippi Period Southeast and the Southern Plains. In The 1931 Excavations at the Sanders Site, Lamar County, Texas: Notes on the Fieldwork, Human Ostenlogy, and Ceramics, by A. T. Jackson, M. S. Goldstein, and A. D. Krieger, pp. 1-7. Archival Series 2. Texas Archeological Research Laboratory, The University of Texas at Austin.

2000bSpiroan Traders, the Sanders Site, and the Plains Interaction Sphere: A Reply to Bruseth, Wilson, and Perttula. Plains Anthropologist 45(171):17-33.

Teltser, P. A.

1993 An Analytic Strategy for Studying Assemblage-Scale Ceramic Variation: A Case Study from Southeast Missouri. American Antiquity 58(3):530-543. 
Wilson, D.

1993 The Sexual Division of Labor at the Sanders Site (41LR2), Lamar County Texas. Caddoan Archeology Newsletter 4(3):6-13.

1994 Division of Labor and Stress Loads at the Sanders Site (41LR2), Lamar County, Texas. Bulletin of the Texas Archeological Society 65:129-160.

1995 Dental Paleopathologies in the Sanders Site (41LR2) Population from Lamar County. Journal of Northeast Texas Archaeology 5:29-59.

1997 Dental Paleopathology in the Sanders (4lLR2) and Mitchell (41BW4) Populations from the Red River Valley, Northeast Texas. Bulletin of the Texas Archeological Society 68:147-159.

Wilson, D. and D. Cargill

1993 Stable Isotope Analysis from the Sanders Site (41LR2). Caddoan Archeology Newsletter 4(3):3.

Wilson, D. and S. Derrick

1996 Cranial Modeling Among the Caddo. The Newsletter of the Friends of the Texas Archeological Research Laboratory 4(2):20-21.

Wilson, L.

1948 Two Small Pipes from the Sanders Site near Direct. The Record 6(7):30. Dallas Archeological Society, Dallas.

Wilson, L. and R. Housewright

1941 Scrapers from Sanders Site, Lamar County. The Record 3(4):19-21. Dallas Archeological Society, Dallas. 